\title{
Energy consumption and carbon emission for tourism transport in World Heritage Sites: a case of the Wulingyuan area in China
}

\author{
Chengcai Tang, Linsheng Zhong, Wenjing Fan and Shengkui Cheng
}

\begin{abstract}
Transport profoundly affects energy use and carbon dioxide emissions in the tourism sector. The Wulingyuan Scenic Area (WSA), a natural heritage destination in China, is chosen for the case study. The energy consumption and carbon emission of 10 types of tourism transportation modes at the destination are measured and analyzed using a bottom-up approach for the period of 1979 to 2010. Scenarios were created to project the effects of single and multiple factors on energy consumption and carbon emission by tourism transportation during 2011-2020. The results showed the following: (a) there is a large difference in energy consumption and carbon emission per capita and per kilometer per capita among the 10 vehicle modes; (b) the monthly energy consumption and carbon emission of tourism transportation differed significantly, the month with the highest (October) are respectively 6.8 and 4 times that of the lowest month (January); (c) the highest annual growth rate of energy consumption and carbon emission are respectively as $32.16 \%$ and $27.98 \%$ during 1979-2010; and (d) the amount of energy consumption and carbon emission in the multiple factor scenarios are lower than that in the reference and single factor scenarios during 2011-2020.
\end{abstract}

Keywords: Energy consumption; carbon emission; tourism transport; world heritage sites; the WSA

\section{Introduction}

Travel and tourism is one of the world's largest sectors, which supports 266 million jobs and generates $9.5 \%$ of global gross domestic product (GDP) (www.wttc.org/ mission/). International tourist arrivals (overnight visitors) reached 1,087 million people in 2013, up 5\% over last year, according to the latest United Nations World Tourism Organization (UNWTO) World Tourism Barometer. Although the tourism industry provides economic benefits, its associated energy consumption and carbon dioxide $\left(\mathrm{CO}_{2}\right)$ emissions are environmentally detrimental (Davenport and Davenport, 2006; Kuo and Chen, 2009). Tourism has been recognized as a significant greenhouse gas (GHG) emissions sector on a global scale by UNWTO and UNEP (2008) and Gössling (2013).

Chengcai Tang is at Beijing International Studies University, School of Tourism Management, Beijing, China. E-mail: tcc5808@163.com Linsheng Zhong (corresponding author) is at the Institute of Geographical Sciences and Natural Resources Research, CAS, Beijing, China. E-mail: zhlsheng@263.net

Wenjing Fan is at Beijing Institute of Graphic Communication, School of Economics and Management, Beijing, China. E-mail: fanjiaruo@126.com Shengkui Cheng is at Institute of Geographical Sciences and Natural Resources Research, CAS, Beijing, China. E-mail: Chengsk@igsnrr.ac.cn
Many organizations and scholars follow the carbon footprint of the tourism industry and promote energy conservation and emissions reduction so the world can cope with global climate change and energy security. In 2005, $\mathrm{CO}_{2}$ emissions caused by tourism development reached 1,307 million metric tons, which accounted for $4.95 \%$ of all $\mathrm{CO}_{2}$ emissions from human activities (UNWTO and UNEP, 2008). Many scholars pay attention to this sector to estimate the contribution of greenhouse gases made by tourism to national and/or regional emissions (Gössling, 2002, 2013; Peeters and Dubois, 2010), account for the tourism carbon footprint at destinations (Munday et al., 2013; Sun, 2014), monitor $\mathrm{CO}_{2}$ emission-intensities in tourism (Gössling et al., 2015), and estimate the tourism-induced electricity consumption (Bakhat and Rosselló, 2011). Some results showed that the energy consumed by the tourism industry in destinations accounts for $60 \%$ of the state's total consumption (Tamirisa et al., 1997). Additionally, Peeters and Dubois (2010) projected that by 2035, the carbon emissions of the tourism industry will increase annually at a rate of $3.2 \%$. Many scholars focused on the impact of energy consumption, and $\mathrm{CO}_{2}$ emissions from tourism (Filimonau et al., 2014; Lee and Brahmasrene, 2013; Katircioglu et al., 2014). Furthermore, the hidden carbon emission impacts from a holiday package tour were 
assessed (Filimonau et al., 2013). The potential economic effects on the tourism industry were analyzed from the introduction of an economy wide carbon tax (Dwyer et al., 2012). A few studies had constructed a new theoretical model and tested the impact of low-carbon literacy on changes in the tourism industry (Horng et al., 2013).

Based on the literature review, a study on energy consumption and carbon emissions from the tourism industry could contribute to the sustainable development of the regions that regard tourism as a pillar industry. The literature reviewed mainly concentrated on current evaluations and future projections of energy use and $\mathrm{CO}_{2}$ emissions in the tourism industry. However, no emphasis has been placed on the energy consumption and carbon emission of the tourism destinations from their initial development to their maturity stages. By conducting this research, basic data and guidance for energy saving and greenhouse gas (GHG) emissions reduction can be provided to destinations during their development.

Previous achievements on energy and $\mathrm{CO}_{2}$ emissions in the tourism industry have mainly been divided it into three sections: transportation, accommodation, and activities (Becken et al., 2003; Gössling et al., 2005). Many studies have indicated that transportation accounts for a significant portion of the energy consumption and $\mathrm{CO}_{2}$ emissions in the tourism industry. The UNWTO and UNEP (2008) stated that $\mathrm{CO}_{2}$ emissions caused by global tourism transportation accounted for $75 \%$ of carbon emissions produced by the tourism industry in 2005. In addition, $\mathrm{CO}_{2}$ emissions caused by tourism transportation accounted for $87 \%$ of carbon emissions produced by the entire tourism industry in Switzerland in 1998 (Nielsen et al., 2010). A survey of the western coast of South Island in New Zealand revealed that transportation accounts for $65-73 \%$ of the energy consumed by local and international travelers (Becken et al., 2003). Moreover, some researchers have projected energy consumption and $\mathrm{CO}_{2}$ emissions for future tourism transportation. Dubois and Ceron (2006) projected that France will experience a 90\% increase in GHG emissions from transportation and a $200 \%$ increase in passengerkilometers in its tourism industry by 2050 . Peeters et al. (2007) projected that carbon emissions from transportation associated with the tourism sector in Europe will rise $90 \%$ by 2020. Therefore, research on energy consumption and carbon emissions for tourism transportation are instrumental, and it could contribute to the development of sustainable tourism and enhance the adaptability of tourism to the challenges of global climate change and energy security. However, relatively few studies on the energy consumption and carbon emission for tourism transportation have been undertaken in developing countries, and insights from such countries could contribute to future conservation measures.

There are different levels of energy consumption and carbon emissions that occur through various tourism transport modes (Gössling, 2002; Becken et al., 2003).
Most of the previous investigations on energy and carbon emissions of tourism transportation focused on a global scale (Gössling, 2002; Peeters and Dubois, 2010), and the country level scale with studies on Switzerland (Nielsen et al, 2010), mainland China (Liu et al., 2011; Wu and Shi, 2011), and Taiwan (Kuo and Chen, 2009; Lin, 2010). However, a few investigations accurately measured energy consumption and carbon emissions of different tourism transportation modes at a specific destinations (Becken and Patterson, 2006; Becken et al., 2003; Howitt et al., 2010), but there were no mentions of study sites in developing countries. Most research on energy consumption and carbon emissions of tourism transport are studied based on current research achievements. A few scholars use a bottom-up method to measure the $\mathrm{CO}_{2}$ emission of four modes of tourism transport in national parks (Lin, 2010); the key point of this method is the clear boundary of each part for the tourism industry and the date collecting for every part.

China's tourism industry is experiencing rapid development, which has resulted in increasing energy consumption and $\mathrm{CO}_{2}$ emissions (Tang et al., 2014). In 2013, China hosted approximately 3.39 billion tourists, who were comprised of 3.26 billion domestic travelers, 129 million inbound tourists, and 98.19 million outbound tourists. The tourism revenue in China amounted to US $\$ 475.93$ billion (CNTA, 2014). Previous investigations on energy consumption for tourism have focused on locations nationwide (Wu and Shi, 2011), such as the city of Chengdu (Liu et al., 2011), the Penghu Islands (Kuo and Chen, 2009), and the local national parks (Lin, 2010). Some researchers used a bottom-up approach to explore the influences of tourism transportation, accommodation, and activities on the total $\mathrm{CO}_{2}$ emissions of the tourism industry over the period between 1990 and 2012 (Tang et al., 2014). $\mathrm{Xu}$ et al. (2011) concentrate on how to develop low-carbon tourism using a quantitative approach. Most previous investigations on energy consumption and carbon emissions for tourism transport in China were based on existing measurements from other counties, except for the one conducted by Lin (2010), where a bottom-up method was used to measure the $\mathrm{CO}_{2}$ emissions of transport. This study attempts to accurately measure the energy consumption of various types of tourism transport tools at a tourism destination and fill the gap in the existing literature.

The development of tourism could provide effective protection for heritage sites and this topic has been researched extensively (Peleggi, 1996; Li et al., 2008; Weaver, 2011) in heritage cities in Europe (Borg et al., 1996), China (Li et al., 2008), the United States (Weaver, 2011), and Singapore (Teo and Huang, 1995). At the end of 2014, there were 47 world heritage sites and all of them have gradually become famous tourist destinations for Chinese and overseas tourists. The Wulingyuan scenic area (WSA) represents the most typical heritage tourism destination in China, and it exemplifies effective protection 
and sustainable development. The 10 types of dominant tourism transport modes used at China's tourism destinations have been offered at the WSA.

The WSA was chosen as a case study because the energy consumption and carbon emission of 10 types of tourism transport modes for the period between 1979 and 2010 was measured and analyzed using a bottom-up approach. In this study, energy consumption and carbon emissions per visitor for various tourism transport modes were estimated. The characteristics of monthly variation for the energy consumption and carbon emission of these modes are also analyzed. In addition, the characteristics of inter-annual variation for the energy consumption and carbon emission of various tourism transport modes are analyzed between the years 1979-2010. Moreover, future scenarios of energy consumption and carbon emission for tourism transport during 2011-2020 are projected. This is done by analyzing a single factor as well as the interactive effects of factors. The research concludes by addressing the issue of energy conservation for tourism destinations with a special focus on world heritage destinations.

\section{Research region}

\subsection{General situation}

The WSA is located between the latitudes $29^{\circ} 16^{\prime} \mathrm{N}-29^{\circ} 24^{\prime} \mathrm{N}$ and the longitudes $110^{\circ} 22^{\prime}-100^{\circ} 41^{\prime} \mathrm{E}$ in China's Hunan Province, with an area of approximately $397.6 \mathrm{~km}^{2}$. The climate in Wulingyuan is subtropical monsoon, with an average annual temperature between $14^{\circ} \mathrm{C} \sim 15^{\circ} \mathrm{C}$, annual precipitation between $1,380.0 \mathrm{~mm} \sim 1,450.0 \mathrm{~mm}$, and a mean annual sunshine time of $1,297 \mathrm{~h}$. The WSA has an interesting geomorphology with a peculiar and attractive landform, ecosystem integrity, a rare geological landscape, and changeable microclimates. In December 1992, the area was listed as a natural heritage site by the United Nations Educational, Scientific and Cultural Organization (UNESCO) and registered into the organization's World Heritage List (Advisory Body Evaluation, n.d.).

With its unique tourism resources, the WSA has become a famous tourism destination and it has attracted tourists from both China and abroad. In the past 30 years, the tourism industry in the WSA has experienced rapid development. According to the Wulingyuan Bureau of Statistics, tourist arrivals increased from 10,000 in 1979 to 14 million in 2010, and tourism receipts increased from tens of thousands to US $\$ 0.83$ billion dollars in the same period, which made the WSA the most important site in the local economy (WBS, 2005, 2011).

\subsection{Study objects}

The research focus of this article is the energy consumption and carbon emission of tourism transport in the WSA of
China. Vehicles were grouped into two categories in this study: fuel-powered and electricity-powered. The former category included six types of transportation modes: a chartered tour bus; a taxi; a motorcycle; a public bus; a self-driving car; and a low-emission bus. The latter category included four types of transportation: a cableway vehicle; a sightseeing elevator; a sightseeing electric streetcar; and an electric yacht.

Most of the visitors to the WSA passed through the city of Zhangjiajie and most accommodation facilities were distributed in the center of the city. Therefore, the following assumptions were made: (a) all of the tourists traveled from Zhangjiajie into Wulingyuan and; (b) the center of the city is the departure point to every scenic spot for all of the tourists.

Figure 1 is the location map of various scenic spots in the WSA, and it should be noted that there is $35 \mathrm{~km}$ from Zhangjiajie to the WSA outer perimeter and around $15 \mathrm{~km}$ to the center of the WSA zone. The distance between the district center and symbolic gate is about $1 \mathrm{~km}$. The distance between the district center and Forest Park is about $15 \mathrm{~km}$. The distance between the district center and Huanglongdong is about $6 \mathrm{~km}$, and the distance between the district center and Baofeng Lake is about $2 \mathrm{~km}$.

\section{Method}

\subsection{Measurement of energy consumption and carbon emission in 2010}

Different types of tourism vehicles require varied energy sources, and the sources have a range of associated efficiencies and carbon emissions. The energy consumption of tourism vehicles was measured according to the number of visitors, distance of travel to the WSA and within the WSA, and energy efficiency of the vehicles in this study. The carbon emission of tourism vehicles was measured according to the $\mathrm{CO}_{2}$ emission coefficient and the amount of energy used.

\subsubsection{The chartered tourist bus and self-driving car}

The energy consumption for the chartered tourist bus and self-driving car was directly affected by transportation distance, energy consumption efficiency, and traffic transport time for each vehicle at a specific time in the WSA. Total energy consumption by these vehicles can be expressed as the following:

$$
\text { Energy }_{\text {comsumption }}=\sum_{i=1}^{n} D_{i} \cdot \lambda_{i} \cdot N_{i}
$$

where $i$ is the certain sort of vehicle, $D_{i}$ is the transport distance per tourist taking a tourism vehicle $i(\mathrm{~km})$ and $\lambda_{i}$ is energy consumption in mega joules (MJ) for tourism 
vehicle $i$ per kilometer $(\mathrm{MJ} / \mathrm{km}) . N_{i}$ is the transport time for a tourism vehicle $i$ at a particular time, which can be expressed as Equation 2 where $V_{\mathrm{i}}$ represents the total number of visitors taking vehicle $i$ with certain seats at a particular time. $V u_{i}$ is the average number of visitors for vehicle $i$ (average load).

$$
N_{i}=\frac{V_{i}}{V u_{i}}
$$

There were a total of 531 chartered tour buses found operating in the WSA through six tourism transport companies. According to China's vehicle classification standard (GB9417-89), fuel consumption per hundred kilometers of all vehicles comes from total amount of vehicles multiple by corresponding fuel consumption per hundred kilometers (Table 1). The 531 transport vehicles traveled $100 \mathrm{~km}$ and depleted 9,747 L diesel normally running in the WSA. The average tourism transport vehicle carries around 36 passengers and depletes $18.36 \mathrm{~L}$ of fuel per hundred kilometers. In 2010, the WSA received 2,510,792 tourists and according to a survey from the management department of the WSA and local taxi company, $80 \%$ of the tourists chose to use a group tour which mainly utilized chartered tour buses. Based on the volume of visitors to the WSA in 2010 the amount of vehicles needed was calculated between various tourism spots. Then, the distance between various tourism spots displayed in Figure 1 was used to determine that distance traveled by all of the chartered tour buses in the WSA. Next, the total fuel consumption per hundred kilometers was counted based on each tourism transport, and the amount of energy consumption of chartered tour bus was counted based on caloric value in diesel.

The data of fuel consumption per hundred kilometers of typical self-driving car models was provided by the Ministry of Industry and Information Technology of China, where various vehicles used an average $9.011 / 100 \mathrm{~km}$ of gasoline (MIITC, 2010). Since there was a lack of data on the type of self-driving vehicle, $9.01 \mathrm{l} / 100 \mathrm{~km}$ was used as the standard fuel consumption per hundred kilometers in

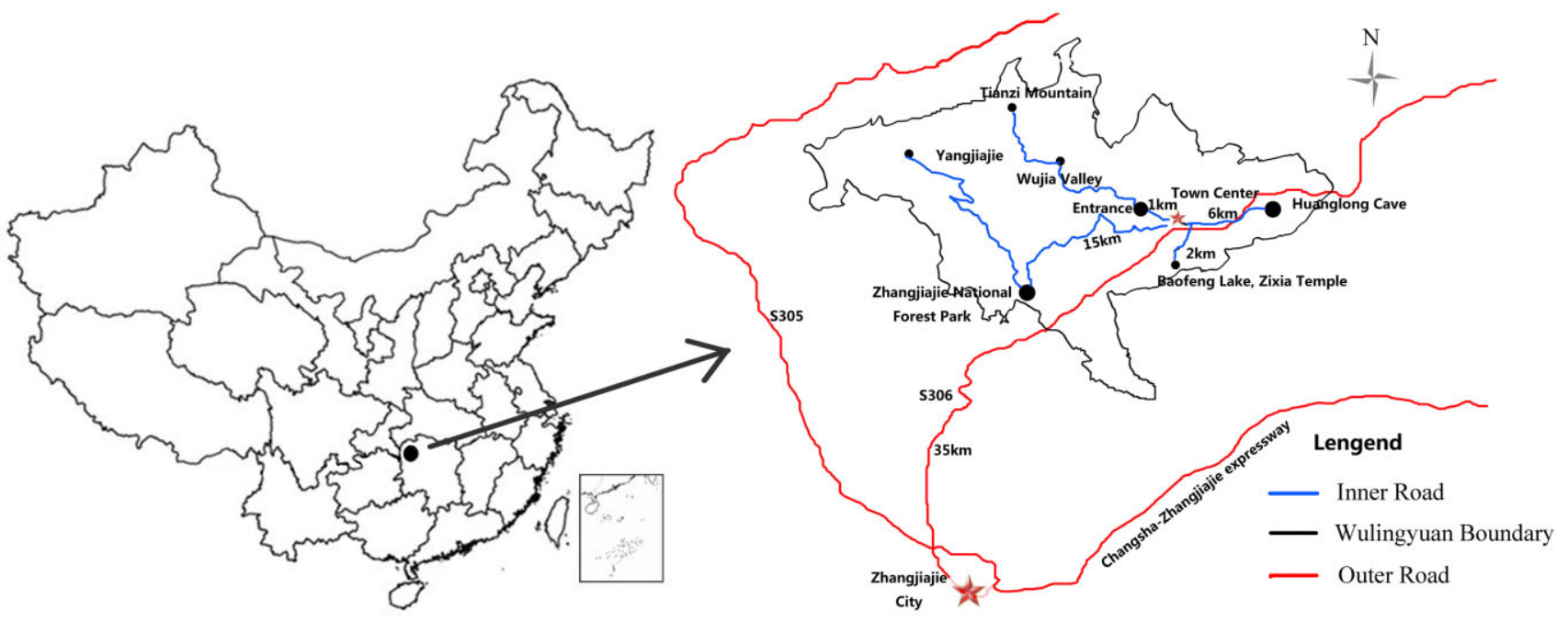

Figure 1. The location map of various scenic spots in the WSA. Source: Author's print from local tour map.

Table 1. Various types of vehicles and fuel consumption per hundred kilometers based on six tourism transport companies

\begin{tabular}{|c|c|c|c|c|c|c|}
\hline Transport company & $\begin{array}{l}\text { Number of } \\
\text { vehicle }\end{array}$ & $>40$ seats & $31-40$ seats & $30-19$ seats & $9-18$ seats & $<9$ seats \\
\hline Taian & 181 & 27 & 131 & 23 & 0 & 0 \\
\hline Yunan & 93 & 40 & 35 & 18 & 0 & 0 \\
\hline Xiangrong & 53 & 0 & 0 & 1 & 1 & 51 \\
\hline Anlong & 126 & 16 & 84 & 26 & 0 & 0 \\
\hline Yangguang & 18 & 0 & 12 & 6 & 0 & 0 \\
\hline Xiangyun & 60 & 0 & 0 & 0 & 60 & 0 \\
\hline Total amount of vehicles & 531 & 83 & 262 & 74 & 61 & 51 \\
\hline fuel consumption per hundred kilometers (L) & & 24 & 20 & 15 & 13 & 12 \\
\hline Total fuel consumption per hundred kilometers for all the vehicles (L) & 9,747 & 1,992 & 5,240 & 1,110 & 793 & 612 \\
\hline
\end{tabular}

Source: Author's survey.

(C) 2015 The Authors. Natural Resources Forum (C) 2015 United Nations 
the WSA. The self-driving tour in the WSA has developed since 2005, in 2010 there were 12,000 vehicles and around 40,000 tourists traveling in the WSA through a self-driving tour. From the survey made by the management department in the WSA, it was determined that all the tourists would travel in core tourism regions, while $80 \%$ of the tourists would go to Baofeng Lake and Huanglong Cave. Based on the distance to various spots, fuel consumption per hundred kilometers $(9.01 \mathrm{l} / 100 \mathrm{~km})$, and distance length, energy consumption could be calculated.

\subsubsection{The low-emission bus, motorcycle, taxi and public bus}

The energy consumption of tourism vehicles, such as the low-emission bus, the motorcycle, the taxi, and the public bus, are measured by day as a unit. The number of lowemission buses in operation is dependent on the number of visitors and the season; an increased number of visitors in peak season require more buses in operation, which leads to more energy consumption. Three modes of travel, including motorcycles, taxis, and buses, are also used by local residents. Therefore, the energy consumed by tourists is calculated by subtracting the local residents' energy consumption from the total energy consumption, according to the proportion of tourists to the total number of passengers. Equation 3 is the measurement model of energy consumption for the four types of tourism transportation, where $\mu_{i}$ is the general energy consumption of tourism vehicles $i ; d_{i}$ is the number of operating days for tourism transportation modes, and $\theta_{i}$ is the proportion of visitors to all passengers of tourism vehicles $i$.

$$
\text { Energy }_{\text {comsumption }}=\sum_{i=1}^{n} \mu_{i} \cdot d_{i} \cdot \theta_{i} \text {. }
$$

The low-emission bus is responsible for the transportation of visitors who travel between tourism attractions within core scenic areas of the WSA. From 1992 to 2010 , there were 197 low-emission buses. Depending on the monthly departure frequency in 2010 from the green transport company, the monthly and annual energy consumption of low-emission buses could be found. According to the study, there is $70 \mathrm{~km}$ of scenic roads in the WSA. Each visitor traveled $40 \mathrm{~km}$ by tourism vehicles per day, which contributed to the energy consumption per passenger per kilometer.

The amount of ownership of various models of motorcycles and their mean energy consumption level was shown in Jia et al. (2010). After communicating with motorcycle operators in the WSA, a questionnaire was designed for motorcycle operators, and 150 of them were chosen as subjects. The result of the questionnaire is shown in Table 2. In July 2010, the price of gasoline used by the motorcycles in the WSA was 1.10 Dollar/l. The peak period in the WSA has 244 days (from April to November), while the slack period has 121 days (from December to March). On average, 1.5 passengers are carried per motorcycle, with a distance of $3 \mathrm{~km}$ each time.

The WSA operates a taxi company, which was founded in December 2006. The company possesses 75 vehicles, including Jetta FV7160G, Jetta 7190CDX and Jetta FV7190GDF, which use diesel and use 7.51 per hundred kilometers, and consume 201 and 151 in peak periods and slack periods. About $90 \%$ of the passengers are tourists. In the WSA, 1/7 of the tourists travel by taxi, having reached a total of 2 million tourists in 2010. The taxi company consumed $640 \mathrm{kWh}$ of electric energy per month.

The bus company in the WSA was founded in 2007. It now has three routes that cover all the main tourism spots with 20 buses. Introduced by the bureau of public transportation, $10 \%$ of the passengers using the public bus are tourists, and 300-500 passengers (400 passengers on average) are carried per day for one vehicle. In conclusion, each public bus consumed 241 of diesel every day.

\subsubsection{The cableway, sightseeing elevators, sightseeing cars and electric yachts}

The type of energy consumption for cableways, sightseeing elevators, sightseeing cars, and electric yachts in the WSA

Table 2. Questionnaire for motorcycle operators

\begin{tabular}{llll}
\hline No. & Questions & Results & \\
\hline 1 & How many people are engaged in transporting tourists by motorcycle & & Around 150 \\
2 & Are you a part-time or full-time motorcycle operator? & Full-time: 100 & \\
\multicolumn{2}{l}{ Questions for full-time operators } & & \\
3 & How much do you earn through operating motorcycle? & Peak period: 3,500 & Slack period: 1,800 \\
4 & How much do you spend on fuel charge? & Peak period: $\$ 2.94$ & Slack period: $\$ 1.76$ \\
5 & What's the percentage of tourists in all the passengers? & Peak period: $50 \%$ & Slack period: $30 \%$ \\
Questions for part-time operators & Peak period: 2,000 & Slack period: 1,000 \\
6 & How much do you earn through operating motorcycle? & Peak period: 15 & Slack period: 7.5 \\
7 & How much do you spend on fuel charge? & Peak period: $60 \%$ & Slack period: $25 \%$ \\
8 & What's the percentage of tourists in all the passengers? & & \\
\hline
\end{tabular}

Source: Author's elaboration. 
is electrical power. The monthly usage for cableway and sightseeing elevators and sightseeing cars was obtained from our survey to the operating company in the WSA in 2010. The usage for electric yachts was measured by rated power and operation time. The measurement of electric power consumption was converted into caloric value. Equation 4 is the measurement model for energy consumption of electric yachts, where $\alpha_{i}$ is the energy consumption of an electric yacht operating at a particular time, and $N_{i}$ is the number of tourism vehicles $i$ operating per unit time. $N_{i}$ is measured in Equation 2.

$$
\text { Energy }_{\text {comsumption }}=\sum_{i=1}^{n} \alpha_{i} \cdot N_{i}
$$

The WSA had two cableways that were used by visitors in 2010. Both of the two cableways were built and started operation in 1997. The electricity data of the cableway and the length of the cableway were obtained from the cableway's operating company. There was also a sightseeing elevator in tourism areas, named Bailong elevator, which was used by visitors, and it came into service in 2005 .

The ten-li gallery boutique route operated a sightseeing electric streetcar, with a $3.4 \mathrm{~km}$ length and it used $30 \mathrm{~kW}$ in electric power. Based on the volume of visitors, the number of seats and electric power of Ten-li gallery, operating frequency, and electricity, the energy consumption per visitor could be calculated.

There were two tourism spots that had electric yachts in the WSA, Baofeng Lake and Huanglong Cave, whose electric power and height data was obtained from their company. Every electric yacht in Baofeng Lake had 56 seats and they had a $0.75 \mathrm{~h}$ long tour, which was $2.5 \mathrm{~km}$. The electric yacht in Huanglong Cave had 20 seats, and it opereated a $0.5 \mathrm{~h}$ tour. Based on the volume of visitors, the number of seats and electric power of Baofeng Lake and Huanglong Cave, operating frequency, and electricity, the energy consumption per visitor could be calculated.

According to NBS (2011), the minimum calorific value of diesel, gasoline, and electricity are $42.65 \mathrm{MJ} / \mathrm{kg}$, 43.07 MJ/kg, and $3.6 \mathrm{MJ} / \mathrm{kWh}$ respectively, and their $\mathrm{CO}_{2}$ emission coefficients are respectively $3.1605 \mathrm{kgCO}_{2} / \mathrm{kg}$, $2.9848 \mathrm{kgCO}_{2} / \mathrm{kg}$, and $0.7980 \mathrm{kgCO}_{2} / \mathrm{kWh}$ (You et al., 2011).

\subsection{Estimation of energy consumption and carbon emission from 1979 to 2009}

Based on the direct measurement of energy consumption and carbon emission of various types of transport in the WSA in 2010, the unit energy consumption and carbon emission can be obtained for each person (p) each time. For example, the energy consumption(MJ/p) and carbon emission $(\mathrm{kg} / \mathrm{p})$ of different tourism transport types for one passenger each time, and the energy consumption (MJ/ $\mathrm{pkm})$ and carbon emission $(\mathrm{kg} / \mathrm{pkm})$ of different tourism transport types for one passenger for one kilometer ( $\mathrm{pkm}$ ). We can obtain the energy consumption and carbon emission of various types of transport from 1979 to 2009 based on the volume of passengers and the distance of transportation, providing that there is no difference in energy consumption and carbon emission for each visitor from 1979 to 2009, referring the unit energy consumption and carbon emission in 2010 .

\section{Results and analysis}

\subsection{Energy consumption and carbon emission per visitor}

Table 3 presents the results of energy consumption and carbon emission per visitor for different modes of tourism transport in the WSA in 2010. The results indicated significant discrepancies in energy consumption and carbon emission per visitor for the 10 tourism transport modes. Among the vehicles listed, the self-driving car had the highest energy consumption and carbon emission per visitor $(55.05 \mathrm{MJ} / \mathrm{p}, 3.5203 \mathrm{~kg} / \mathrm{p})$, and the lowest energy consumption and carbon emission was from electric yacht $(0.44 \mathrm{MJ} / \mathrm{p}, 0.0979 \mathrm{~kg} / \mathrm{p})$. The variance in their consumption is mainly attributed to differences in traffic type and transport distance.

For the different tourism transport modes, significant differences were observed in energy consumption and carbon emission on per passenger-kilometer, which describes the traffic of each visitor each way per kilometer. The sightseeing elevator consumed the most energy per passenger-kilometer $(3.28 \mathrm{MJ} / \mathrm{pkm}, 0.6801 \mathrm{~kg} / \mathrm{pkm})$, the electric yacht and the public bus scored respectively the lowest energy $(0.16 \mathrm{MJ} / \mathrm{pkm})$ and carbon emission $(0.0159 \mathrm{~kg} / \mathrm{pkm})$.

\subsection{Energy consumption and carbon emission per month}

Table 4 presents respectively, the monthly variation in energy consumption and carbon emission for the different transport modes in the WSA in 2010. The average amount of monthly energy consumption and carbon emission for tourism transport was 9.31 tera joules (TJ) (coefficient of variation was $47.79 \%$ ) and 877.94 carbon emissions ( $(t)$ (coefficient of variation was $38.52 \%$ ). The maximum month of energy consumption and carbon emission (October, 16.17 TJ, 1,389.47 t) was respectively 6.8 times and 4 times higher than those of the minimum month (January, $2.37 \mathrm{TJ}$, $347.86 \mathrm{t}$ ); more energy is being consumed and more carbon emission from April to November than from December to the following March. It should be noted that the energy consumption and carbon emission on tourism transport are closely related with tourism high and low seasons, which is caused by managers arranging the amount of tourism transport modes based on the number of visitors. 
Table 3. Energy consumption and carbon emission of per passenger-kilometer for different tourism transport modes

\begin{tabular}{|c|c|c|c|c|c|}
\hline Index & $\begin{array}{l}\text { Low-emission } \\
\text { bus }\end{array}$ & Cableway & $\begin{array}{l}\text { Sightseeing } \\
\text { elevator }\end{array}$ & $\begin{array}{l}\text { Sightseeing electric } \\
\text { streetcar }\end{array}$ & $\begin{array}{r}\text { Electric } \\
\text { yacht }\end{array}$ \\
\hline Annual volume of visitor $(10,000)$ & 532.08 & 304.13 & 181.69 & 112.71 & 117.66 \\
\hline Unit transport distance $\mathrm{km}$ & 40 & 1.56 & 0.3127 & 3.4 & 2.84 \\
\hline Energy consumption per capita (MJ/p) & 8.83 & 2.4 & 1.03 & 5.65 & 0.44 \\
\hline Energy consumption per capita per kilometer (MJ/pkm) & 0.22 & 1.54 & 3.28 & 1.66 & 0.16 \\
\hline Carbon emission per capita $(\mathrm{kg} / \mathrm{p})$ & 0.6382 & 0.4970 & 0.2278 & 1.2539 & 0.0979 \\
\hline Carbon emission per capita per kilometer ( $\mathrm{kg} / \mathrm{pkm})$ & 0.0160 & 0.3029 & 0.6801 & 0.3688 & 0.0350 \\
\hline Index & $\begin{array}{l}\text { Chartered } \\
\text { tour bus }\end{array}$ & $\begin{array}{l}\text { Self-driving } \\
\text { car }\end{array}$ & Taxi & $\begin{array}{l}\text { Public } \\
\text { bus }\end{array}$ & Motorcycle \\
\hline Annual volume of visitor $(10,000)$ & 251.08 & 4 & 200 & 33.32 & 86.84 \\
\hline Unit transport distance $\mathrm{km}$ & 44 & 52.67 & 6.5 & 10 & 3 \\
\hline Energy consumption per capita (MJ/p) & 11.13 & 55.05 & 8.11 & 1.88 & 1.89 \\
\hline Energy consumption per capita per kilometer (MJ/pkm) & 0.25 & 1.05 & 1.24 & 0.19 & 0.63 \\
\hline Carbon emission per capita $(\mathrm{kg} / \mathrm{p})$ & 0.8244 & 3.5203 & 0.5999 & 0.1593 & 0.1312 \\
\hline Carbon emission per capita per kilometer $(\mathrm{kg} / \mathrm{pkm})$ & 0.0206 & 0.1883 & 0.0300 & 0.0159 & 0.0437 \\
\hline
\end{tabular}

Source: Author's calculation from Wulingyuan Bureau of Statistics (2011).

In addition, there was uncertainty in the monthly difference of energy consumption and carbon emission for the different transport modes. The differences were slight in the monthly changes of energy consumption and carbon emission of the cableway, the sightseeing elevator, and sightseeing tram, with a variation coefficient of $2.23 \%$ $10.86 \%$, whereas other tourism transport modes have greater differences with a variation coefficient of more than $44 \%$. The low-emission bus had the highest monthly average consumption $(3.92 \mathrm{TJ})$ and carbon emission $(282.96 \mathrm{t})$, which were respectively 91 times and 73 times higher than the lowest monthly energy consumption (Electric yacht, $0.04 \mathrm{TJ}$ ) and carbon emission (Public bus, $3.88 \mathrm{t}$ ) in 2010.

The energy consumption and carbon emission of various tourism transport modes in 2010 are shown in Table 4. The results indicate that the total energy consumption and carbon emission of all kinds of tourism transports in the WSA reached respectively $111.69 \mathrm{TJ}$ and $10,535.25 \mathrm{t}$. Among all the transports, the vehicles that had more fuel depletion also had higher unit energy consumption and carbon emission. For example, the low-emission bus had the highest energy consumption and carbon emission, at $47.01 \mathrm{TJ}$ and $3,395.49 \mathrm{t}$ respectively, accounting for $42.09 \%$ and $32.23 \%$ of the total energy consumption and carbon emission.

\subsection{Energy consumption and carbon emission per year}

Based on the volume of visitors in the WSA from 1979 to 2010 and the energy consumption and carbon emission per capita of each type of vehicle in 2010 (Table 3), the energy consumption and carbon emission by tourism transport were calculated per visitor to the WSA from 1979 to 2010 for each different transport mode (Figure 2).
The highest annual growth rate of energy consumption and carbon emission were respectively $32.16 \%$ and $27.98 \%$ during 1979-2010. Energy consumption of tourism transportation increased from $0.03 \mathrm{TJ}$ in 1979 to $111.52 \mathrm{TJ}$ in 2010 (Figure 2), carbon emission increased from $5.03 \mathrm{t}$ in 1979 to 10,535.26 t in 2010 (Table 5). Figures 2 and 3 illustrate the following results.

According to data obtained during the last four years, the proportion of each type of tourism transportation mode to the total amount of energy consumed was listed as follows: $22.94 \%$ (chartered tour bus), $46.27 \%$ (low-emission bus), $13.31 \%$ (taxi), 6.79\% (cableway), 5.38\% (sightseeing tram), $1.66 \%$ (self-driving car), $1.35 \%$ (motorcycle), $1.29 \%$ (sightseeing elevator), $0.52 \%$ (public bus), and $0.50 \%$ (electric yacht). Therefore, the chartered tour bus, lowemission bus, and taxi consumed the most energy, which accounted for $82.52 \%$ of all energy consumption. Examination of each vehicle is instrumental in reducing carbon emissions and conserving energy for tourism transport.

With diversification of tourism vehicles, the proportional energy consumption for the chartered tour bus, electric yacht, taxi, motorcycle, low-emission bus, and cableway revealed a decreasing trend during 1979 to 2010. For example, the chartered tour bus proportion declined from $100 \%$ in 1979 to $25.05 \%$ in 2010 , and the taxi proportion declined from $33.57 \%$ in 1990 to $14.54 \%$ in 2010 . This showed that in the past 32 years, with the further development of the internal scenic spots, the internal transport consumed more energy.

The proportional consumption of the sightseeing tram, sightseeing elevator, and the self-driving car has been increasing slightly each year. For example, the sightseeing tram increased from $0.98 \%$ in 2000 to $5.71 \%$ in 2010 . Although the amount of energy consumption by the 


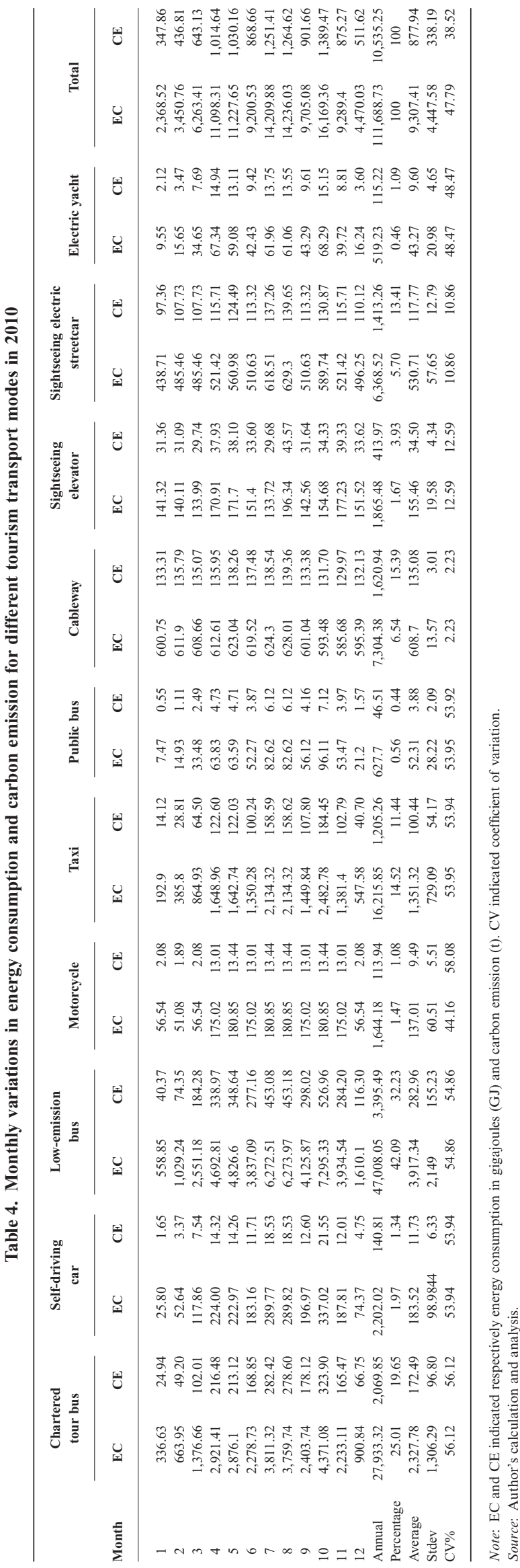

self-driving car was low, it tended to rise annually. With the increasing amount of private car usage and the development of the self-driving tour in China, for reducing the energy consumption and carbon emissions on self-driving tour in world heritage sites, it should be guided reasonably that the proportional energy consumption of the public bus appeared stable at about $0.5 \%$ throughout the duration of the study. Because the public bus could save more energy and reduce more carbon emissions for the tourism transport, the public bus should be encouraged to provide services to indigenous residents and tourists.

The amount of energy consumption and carbon emission of various tourism transport modes from 1979 to 2010 were calculated based on the results of energy consumption per capita of tourism vehicles and the volume of visitors during 1979, 1989, 1995, 2000, 2005, and 2010. The results indicate that the consumption of diesel, gasoline, and electricity increased through the years from 1979 to 2010 . In 1979, only $1.59 \mathrm{t}$ of diesel was consumed. The figure soared to $1,722.41 \mathrm{t}$ (diesel), $510.14 \mathrm{t}$ (gasoline) and 4,472.5 thousand kWh (electricity) in 2010. The vehicles that depend on diesel became less popular when the WSA began to upgrade its green transportation and start using vehicles with more ecofriendly gasoline and electricity.

\subsection{Scenario analysis}

\subsubsection{Scenario setting}

Because energy consumption through tourism transport is mainly determined by the transport mode, the average load factor, and the travel distance, these parameters were selected as independent variables in three scenarios created to determine energy usage in the future. In addition, the interactive effect of multiple factors was also analyzed for each scenario. According to the analysis results of energy consumption for various tourism transport modes in the WSA during 2007-2010, the total energy consumed by the chartered tour bus, the low-emission bus, and the taxi accounted for $82.52 \%$ of the total energy consumption by tourism transport. Therefore, these modes were also chosen as parameters in the scenarios on low carbon transport. Energy consumption by tourism transport in 2010 was used as a reference year for the scenario. All scenarios are presented in Table 6.

The projected number of visitors to the WSA during 2011-2020 was obtained from Wulingyuan's tourism master planning data for 2006-2020. In addition, the number of visitors transported by a certain type of transport mode for the period of 2011-2020 was calculated based on its proportional situation in the latest four years. The energy consumption per visitor-kilometer and travel distance for the chartered tour bus, the low-emission bus, and the taxi were obtained from data presented in Table 5. Two lowemission electric buses that were purchased by a local tourism company in 2011 from Shanghai Ruihua Group 


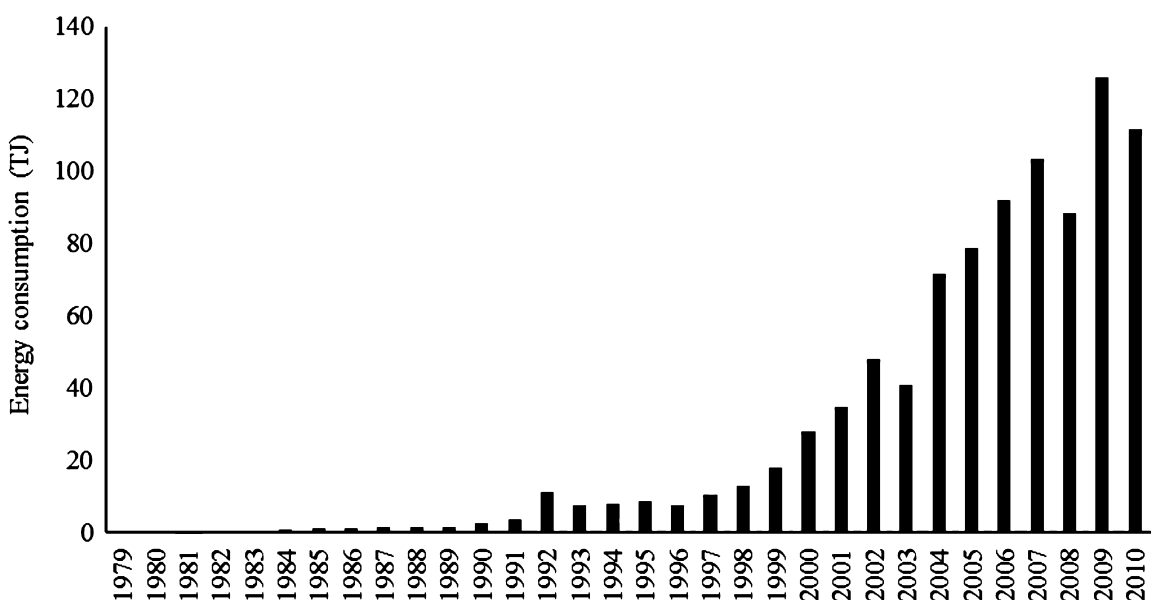

Figure 2. Inter-annual variability on energy consumption of tourism transport from 1979 to 2010. Source: Author's calculation from Wulingyuan Bureau of Statistics $(2005,2011)$.

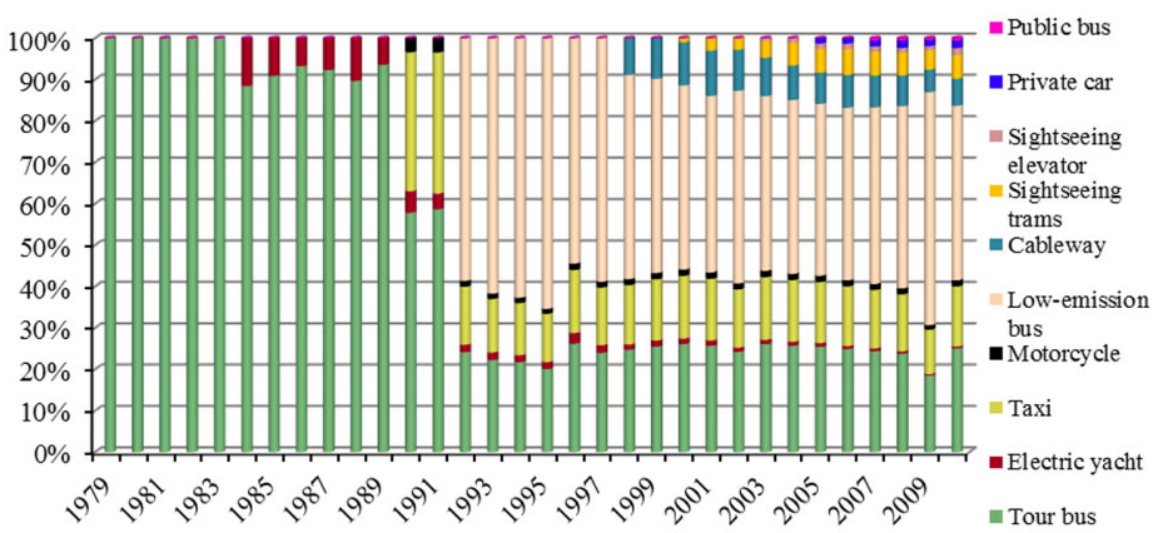

Figure 3. Inter-annual variability of the structure of energy consumption for various travel modes of transport from 1979 to 2010. Source: Author's calculation from Wulingyuan Bureau of Statistics $(2005,2011)$.

Co., Ltd., in China were chosen for the scenario study. This type of bus consumes $40 \mathrm{kWh}$ per 100 miles and holds 24 passengers, and has an energy consumption and carbon emission per visitor-kilometer of $0.06 \mathrm{MJ}$ and $0.0133 \mathrm{~kg}$. Energy consumption data in the reference scenario, in addition to the single and multiple factor scenarios, was analyzed for tourism transport in the WSA during 20112020. The amount of consumed energy and carbon emission in the reference scenario for tourism transport from 2011 to 2020 are at the annual growth rate of $8.75 \%$.

\subsubsection{Scenario analysis on single factor effect}

Tables 7 and 8 respectively present the scenario analysis results for the single factor effect on energy consumption and carbon emission by tourism transport in the WSA. Scenario TS1 (the scenario of transportation mode), TS2, and TS3 assess the impact of visitors on energy consumption and carbon emission by taking different transportation modes. The varied proportions of tourism transport modes for these three simulations were shown as Tables 7 and 8. The results revealed that ETS1 (the scenario of the energy consumption for transportation mode 1), ETS2, and ETS3 respectively saved $13.42 \%$, $33.55 \%$, and $67.10 \%$ more energy than that in the reference scenario, and respectively reduced $3.99 \%$ (CTS1), the scenario of the carbon emission for transportation mode (1), 9.97\% (CTS2), and 19.95\% (CTS3) more carbon emission than that in the reference scenario, which indicates that switching tourism transport modes significantly influences energy consumption and carbon emission. Since the energy consumption and carbon emission per visitor-kilometer of the low-emission electric car $(0.06 \mathrm{MJ} / \mathrm{pkm}, 0.0133 \mathrm{~kg} / \mathrm{pkm})$ is far lower than that of the low-emission bus $(0.22 \mathrm{MJ} / \mathrm{pkm}, 0.016 \mathrm{~kg} /$ $\mathrm{pkm})$, chartered tour bus $(0.25 \mathrm{MJ} / \mathrm{pkm}, 0.0206 \mathrm{~kg} / \mathrm{pkm})$, and taxi $(1.24 \mathrm{MJ} / \mathrm{pkm}, 0.03 \mathrm{~kg} / \mathrm{pkm})$, the total amount of energy consumption and carbon emission of tourism transport significantly declined when more tourists chose the low-emission electric car for their transport. 
Chengcai Tang et al. / Natural Resources Forum 39 (2015) 134-150
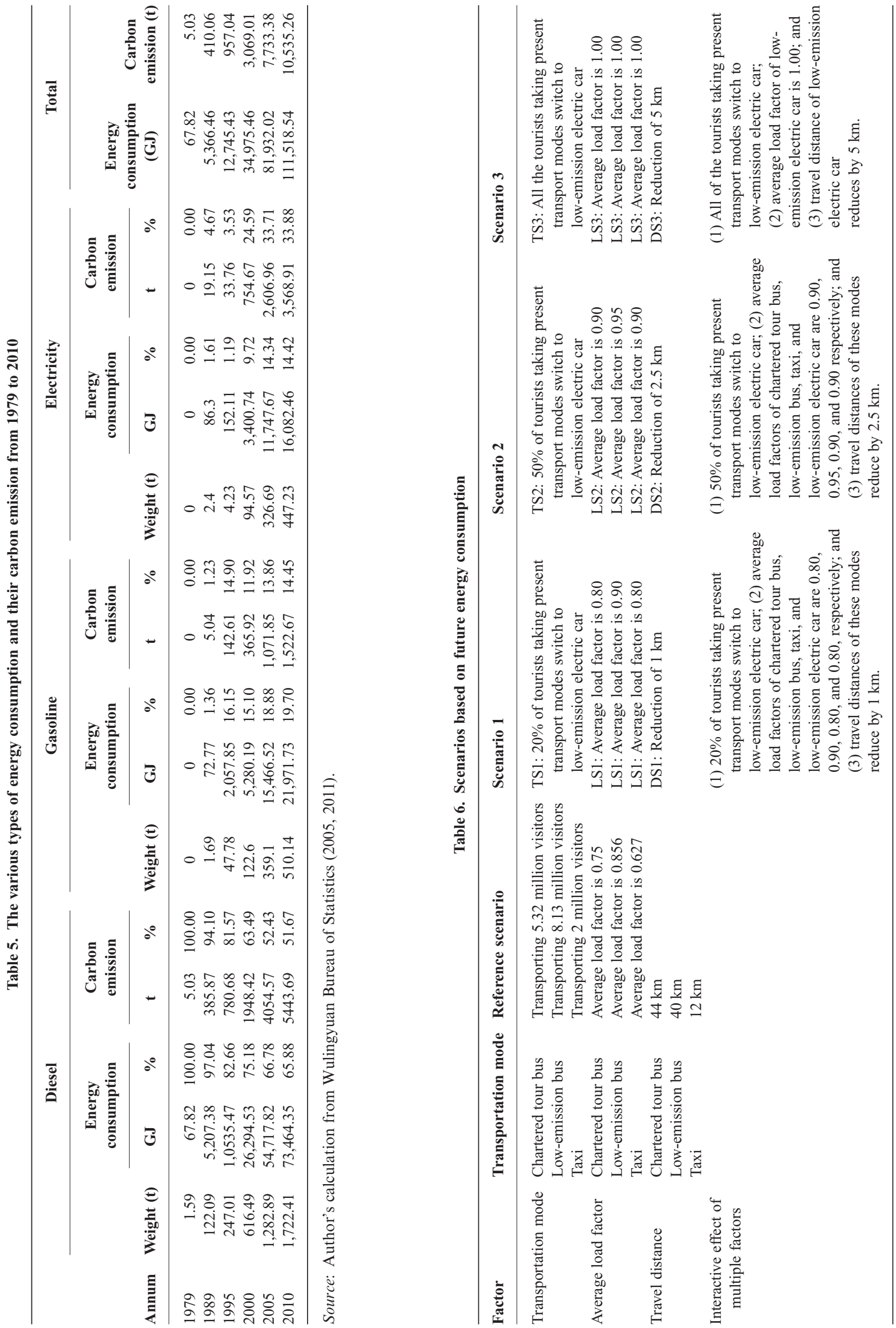


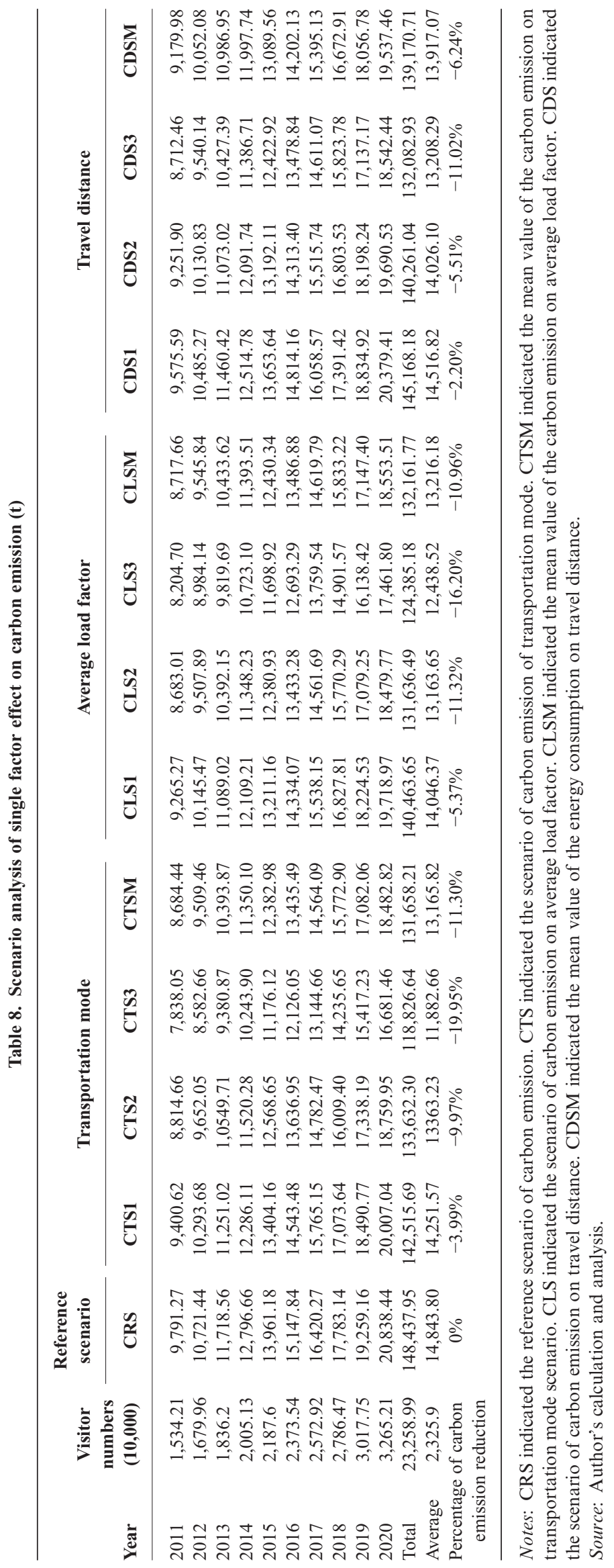


Table 9. Scenario of the interactive effects of multiple factors during 2011-2020

\begin{tabular}{|c|c|c|c|c|c|c|c|c|}
\hline \multirow[b]{2}{*}{ Year } & \multicolumn{4}{|c|}{ Energy consumption (TJ) } & \multicolumn{4}{|c|}{ Carbon emission(t) } \\
\hline & EMS1 & EMS2 & EMS3 & EMSM & CMS1 & CMS2 & CMS3 & CMSM \\
\hline 2011 & 133.75 & 89.86 & 41.57 & 88.39 & $10,534.51$ & $8,918.17$ & $7,121.42$ & $8,858.03$ \\
\hline 2012 & 146.46 & 98.40 & 45.52 & 96.79 & $11,535.29$ & $9,765.40$ & $7,797.96$ & $9,699.55$ \\
\hline 2013 & 160.08 & 107.55 & 49.75 & 105.79 & $12,608.09$ & $10,673.60$ & $8,523.18$ & $10,601.63$ \\
\hline 2014 & 174.80 & 117.44 & 54.33 & 115.53 & $13,768.04$ & $11,655.57$ & $9,307.32$ & $11,576.97$ \\
\hline 2015 & 190.71 & 128.13 & 59.27 & 126.04 & $15,020.95$ & $12,716.24$ & $10,154.30$ & $12,630.50$ \\
\hline 2016 & 206.92 & 139.02 & 64.31 & 136.75 & $16,297.69$ & $13,797.09$ & $11,017.38$ & $13,704.05$ \\
\hline 2017 & 224.30 & 150.70 & 69.71 & 148.24 & $17,666.71$ & $14,956.06$ & $11,942.86$ & $14,855.21$ \\
\hline 2018 & 242.92 & 163.20 & 75.50 & 160.54 & $19,133.03$ & $16,197.40$ & $12,934.10$ & $16,088.18$ \\
\hline 2019 & 263.08 & 176.75 & 81.77 & 173.87 & $20,721.10$ & $17,541.80$ & $14,007.65$ & $17,423.52$ \\
\hline 2020 & 284.66 & 191.24 & 88.47 & 188.12 & $22,420.26$ & $18,980.26$ & $15,156.29$ & $18,852.27$ \\
\hline Total & $2,027.69$ & $1,362.29$ & 630.22 & $1,340.06$ & $159,705.67$ & $135,201.59$ & $107,962.46$ & $134,289.91$ \\
\hline Average & 202.77 & 136.23 & 63.02 & 134.01 & $15,970.57$ & $13,520.16$ & $10,796.25$ & $13,428.99$ \\
\hline $\begin{array}{l}\text { Percentage of energy } \\
\text { conserved and carbon } \\
\text { emission reduction }\end{array}$ & $-1.78 \%$ & $-34.01 \%$ & $-69.47 \%$ & $-35.09 \%$ & $7.59 \%$ & $-8.92 \%$ & $-27.27 \%$ & $-9.53 \%$ \\
\hline
\end{tabular}

Notes: EMS indicated the scenario of energy consumption of the interactive effects of multiple factors. EMSM indicated the scenario of the mean value of the energy consumption on the interactive effects of multiple factors. CMS indicated the scenario of carbon emission of the interactive effects of multiple factors. CMSM indicated the scenario of the mean value of the carbon emission on the interactive effects of multiple factors. Source: Author's calculation and analysis.

Scenarios ELS1, ELS2, and ELS3 were created to assess the impact of average load factors on energy consumption and carbon emission. The switched average load factors of tourism transport modes for these three simulations were shown in Tables 7 and 8. The simulation results show that scenarios ELS1, ELS2, and ELS3 respectively reduced energy consumption by $8.62 \%, 15.75 \%$, and $21.56 \%$ more than the reference scenarios because energy consumption declines as the average number of visitors per trip increases. Also, the following scenarios respectively reduced the carbon emission than the reference scenario: 5.37\% (CLS1), $11.32 \%$ (CLS2), and $16.20 \%$ (CLS3). Given the fixed number of total tourists, an increase in the number of passengers in all vehicles effectively reduces annual energy consumption and carbon emission through tourism transport.

Scenarios EDS1, EDS2, and EDS3 were created to determine the influence of travel distance on energy consumption. The reductions in mileage of the tourism transport modes for the three simulations are shown in Table 7. These results demonstrate that scenarios EDS1, EDS2, and EDS3 respectively reduce energy consumption by $3.44 \%, 8.61 \%$, and $17.22 \%$ more than that in the reference scenarios (ERS, 2,064.51 TJ), and respectively reduce $2.20 \%$ (CDS1), 5.51\% (CDS2), and 11.02\% (CDS3) more carbon emission than that in the reference scenario (CRS, $148,437.95 \mathrm{t}$ ), which indicates that reducing travel distances can also significantly reduce energy consumption and carbon emission.

In sum, in the scenarios to test the single factor effects on energy consumption for the period of 2011-2020, our findings indicated that switching transport modes (ETS3 and CTS3) consumes the least amount of energy
$(679.23 \mathrm{TJ})$ and reduces the most amount of carbon emission (11882.66 t), and it can save $67.10 \%$ of energy consumed and reduce $19.95 \%$ of carbon emission in the reference scenario (2064.51 TJ, $14843.80 \mathrm{t})$.

\subsubsection{Scenario analysis of the interactive effects of multiple factor}

Table 9 and Figure 4 present scenario analysis results on the interactive effects of multiple factors on energy consumption for tourism transport. The energy consumed in the multiple factor scenarios is lower than that in the reference and single factor scenarios for the same period. Relative to energy consumption in the reference scenario $(2061.51 \mathrm{TJ})$, the scenario of the interactive effects of multiple factors (EMS3, 630.22 TJ; CMS3, 107,962.46 t) could save $69.47 \%$ of energy and reduce $27.27 \%$ of carbon emission, whereas the single factor scenario (ETS3, 679.23 TJ; CTS3, $118,826.6$ t) could save $67.10 \%$ of energy and reduce $19.95 \%$ of carbon emission (Figure 5). Among all scenarios, EMS3 and CMS3 are the most energy-saving and low carbon modes where all visitors who take current transport modes switch to low-emission electric cars. The average load factor of this type of vehicle is 1.00 and travel distances are reduced by $5 \mathrm{~km}$.

\section{Conclusion}

World heritage sites protect heritage and provide environmental education and tourism services. As a source for local revenue, the tourism industry is instrumental in balancing the protection of Chinese heritage sites and the 


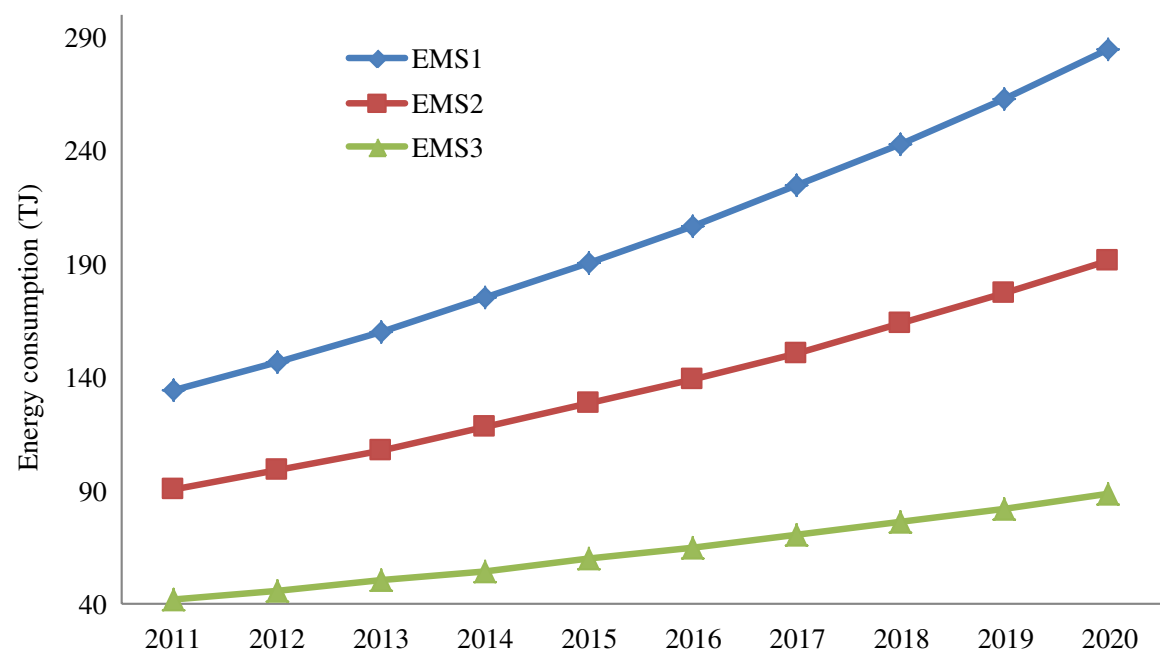

Figure 4. Scenario analysis on the interactive effects of multiple factors to energy consumption during 2011-2020. Source: Author's calculation.

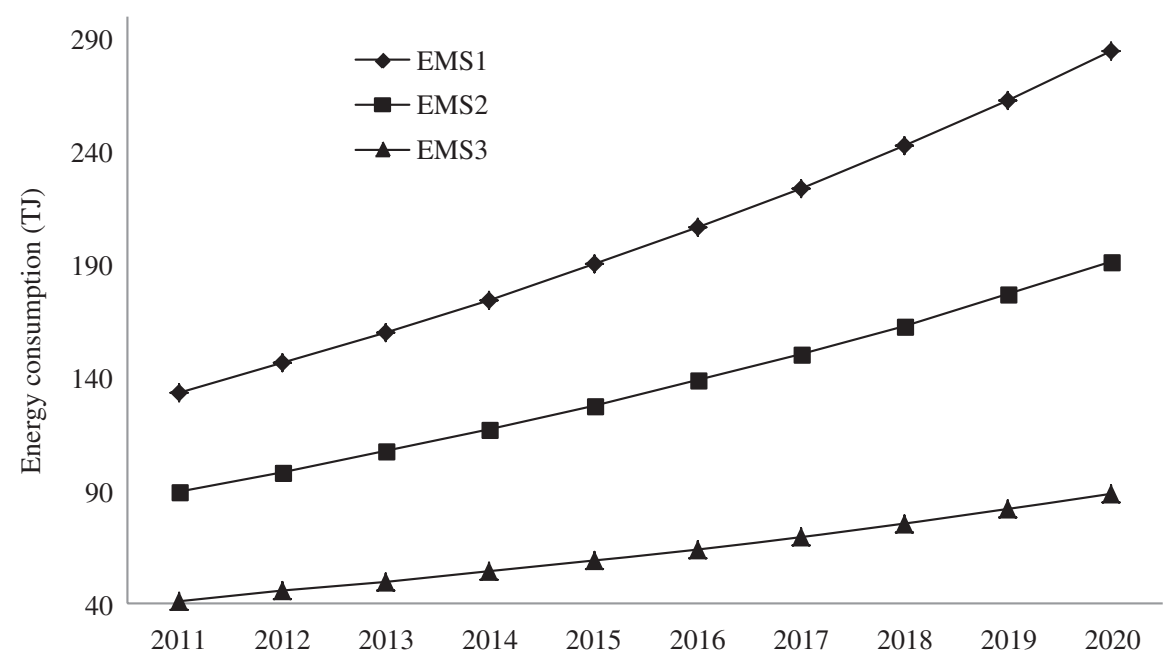

Figure 5. Scenario analysis on the interactive effects of multiple factors to carbon emissions during 2011-2020.

Source: Author's calculation and analysis.

promotion of sustainable development for local communities. However, a rapid increase in the number of tourists has led to rapid development in all sectors of tourism; thus, the amount of energy consumption through tourism has also risen sharply. A study on energy consumption of tourism transport could contribute to the development sustainable tourism and enhance the adaptability of tourism to the effects global climate change and promote energy security.

\subsection{Conclusions}

The WSA is used as an example and a bottom-up approach is adopted to measure and analyze the energy consumption and carbon emission of 10 tourism vehicles from the initial stage of development (1979) to current situation (2010). The results indicated the following.

There are differences in energy consumption and carbon emission per capita and per kilometer per capita among the 10 vehicle modes. For instance, a self-driving car had the highest energy consumption and carbon emission per visitor $(55.05 \mathrm{MJ} / \mathrm{p}, \quad 3.5203 \mathrm{~kg} / \mathrm{p})$, whereas the electric yacht had the lowest $(0.44 \mathrm{MJ} / \mathrm{p}, 0.0979 \mathrm{~kg} / \mathrm{p})$. Meanwhile, the sightseeing elevator had the highest energy consumption and carbon emission per passenger-kilometer (3.28 MJ/pkm, $0.6801 \mathrm{~kg} / \mathrm{pkm})$, while the electric yacht and the public bus respectively scored the lowest energy $(0.16 \mathrm{MJ} / \mathrm{pkm})$ and carbon emission $(0.0159 \mathrm{~kg} / \mathrm{pkm})$.

In addition, the monthly energy consumption and carbon emission of tourism transportation differed significantly. 
The month with highest energy consumption and carbon emission (October) was respectively 6.8 and 4 times more than the lowest month (January). More energy was consumed and more carbon emission was discharged from April to November and less energy was consumed and less carbon emission was discharged from December to the following March.

Moreover, the highest annual growth rate of energy consumption and carbon emission was respectively $32.16 \%$ and $27.98 \%$ during 1979-2010. Energy consumption of tourism transportation increased from $0.03 \mathrm{TJ}$ in 1979 to $111.52 \mathrm{TJ}$ in 2010 and carbon emission increased from $5.03 \mathrm{t}$ in 1979 to $10,535.26 \mathrm{t}$ in 2010. In 1979 , only $1.59 \mathrm{t}$ of diesel was consumed, the figure then soared to $1,722.41 \mathrm{t}$ (diesel), $510.14 \mathrm{t}$ (gasoline), and 4,472.5 thousand $\mathrm{kWh}$ (electricity) in 2010. During the most recent years, the proportional energy consumption of each of the 10 tourism transport modes was $25.01 \%$ (chartered tour bus), $42.09 \%$ (low-emission bus), $14.52 \%$ (taxi), 6.54\% (cableway), 5.70\% (sightseeing electric streetcar), $1.97 \%$ (self-driving car), $1.47 \%$ (motorcycle), $1.67 \%$ (sightseeing elevator), $0.56 \%$ (public bus), and $0.46 \%$ (electric yacht).

Furthermore, the amount of energy consumption and carbon emission in the multiple factor scenarios were lower than that in the reference and single factor scenarios during 2011-2020. Relative to the energy consumption and carbon emission in the reference scenario $(2,064.51 \mathrm{TJ}, 148,437.95 \mathrm{t})$, the scenario of the interactive effect of multiple factors (EMS3, 630.22 TJ; CMS3, $107,962.46 \mathrm{t}$ ) could save $69.47 \%$ of energy currently used and reduce $27.27 \%$ of carbon emission currently emitted.

\subsection{Discussion}

More scholars are paying attention to the impact of tourism transport on air pollutants (Saenz-de-Miera and Rosselló, 2013, 2014) and carbon dioxide emissions (Kuo and Chen, 2009; Mayor and Tol, 2010). The results of this paper could compensate for deficiencies in existing research that mainly focuses on the evaluation and projection of energy consumption and carbon emission for the tourism transport in a given year or at a certain region (Tamirisa et al., 1997; Gössling, 2002; Dubois and Ceron, 2006; Nielsen et al., 2010). The tourism transport modes in different countries are influenced by several factors, and one includes the stage of economic development. Many scholars use existing research results to estimate energy consumption of tourism transport for specific regions (Gössling, 2002; Kuo and Chen, 2009; Nielsen et al., 2010; Peeters and Dubois, 2010; $\mathrm{Wu}$ and Shi, 2011). However, limited research has been conducted to directly measure energy consumption of tourism transportation at tourist destinations. The energy consumption and carbon emission of per visitor-kilometer for the 10 types of tourism transport modes could provide more insights for further research on energy consumption in developing countries, especially in China.

The diversity of energy efficiency of various vehicles contributed to the great difference in energy consumption per passenger-kilometer. The transport energy efficiency of China's self-driving car $(1.05 \mathrm{MJ} / \mathrm{pkm})$ and taxi $(1.24 \mathrm{MJ} /$ $\mathrm{pkm})$ are markedly lower than that of EU $(1.7 \mathrm{MJ} / \mathrm{pkm})$, which may be due to the low mean energy consumption and high load rate of China's self-driving car and taxi.

In practice many factors are implemented together to obtain optimal energy conservation and emission reduction in tourist destinations. Energy consumption and carbon emission from tourism transport modes in the WSA for the period of 2011-2020 were projected through different scenarios by taking into account of the effect of single factor and multiple factors. This method of scenario projecting could promote energy conservation and carbon emission reduction, as well as provide more accurate projections of energy consumption and $\mathrm{CO}_{2}$ emissions at tourism destinations.

\subsection{Suggestions}

The following suggestions are listed for the energy conservation and low carbon development of tourism transport in the world heritage sites. High energy efficiency and lower carbon emission of transport modes should be encouraged to protect world heritage sources and the environment in the world heritage sites. Technology development should focus on transportation energy reduction. It is important to restrict high unit energy consumption of the transport modes. The production of electricity will discharge air pollution and solid wastes in the production region, but compared to other types of energy such as gasoline and electricity, causes relatively less pollution in the consumption region. The environmental pollution and the ecology construction in the production region are more regulated by national construction standards.

The scientific research and guidance to the department of tourism and transport management should be enhanced in energy consumption and carbon emission of tourism transport. The department of tourism transport management should arrange the number of vehicles based on the volume of visitors during the peak and slack periods. It is necessary to restrict access of private cars to tourist sites. Tourist parking could be made available at a certain distance away from the sites, and then visitors would be shuttled to the park entrances by electric buses in the WSA.

As global climate change and energy security issues become increasingly prominent, energy conservation technologies associated with transportation have recently emerged. The findings of this study indicated that energy consumption and carbon emission can be effectively reduced by implementation of different methods cited in this study. The managers of the WSA can monitor the 
proposed changes through activity management, regulation control, and price adjustment.

\section{Acknowledgements}

We appreciate all the advice from the reviewers for their very insightful comments that have contributed materially to improving this paper. We would also like thank the joint support from the following foundations: National Natural Science Foundation of China (No. 41301161 and No. 41171435), and the Humanity and Social Science Foundation of the Ministry of Education in China (No. 13YJC630144) and the China Postdoctoral Science Foundation funded project (No. 2013M530711).

\section{References}

Advisory Body Evaluation, n.d.. Wulingyuan Scenic and Historic Interest Area. Available at http://whc.unesco.org/en/list/640 (accessed 10 March 2014).

Bakhat, M., Rosselló, J., 2011. Estimation of Tourism-Induced Electricity Consumption: The Case Study of Balearics Islands, Spain” Energy Economics: 437-444.

Becken S., Patterson, M., 2006. Measuring national carbon dioxide emissions from tourism as a key step towards achieving sustainable tourism. Journal of Sustainable Tourism 14(4): 323-338.

Becken, S., Simmons, D.G., Frampton, C. 2003. Energy use associated with different travel choices. Tourism Management 24(3): 267-277.

Borg, J.V.D., Costa, P., Gotti, G., 1996. Tourism in European heritage cities. Annals of Tourism Research 23(2): 306-321.

China National Tourism Administration (CNTA), 2014. The yearbook of China Tourism statistics. Beijing: China Travel \& Tourism Press, (in Chinese)

Davenport, J., Davenport, J.L., 2006. The impact of tourism and personal leisure transport on coastal environments: A review. Estuarine Coastal and Shelf Science 67(2): 280-292.

Dubois, G., Ceron, J.P., 2006. Tourism/leisure greenhouse gas emissions forecasts for 2050: Factors for change in France. Journal of Sustainable Tourism 14(2): 172-191.

Dwyer, L., Forsyth, P., Spurr, R., 2012. Wither Australian tourism? Implications of the Carbon Tax. Journal of Hospitality and Tourism Management 19(1): 1-16.

Filimonau, V., Dickinson, J., Robbins, D., 2014. The carbon impact of short-haul tourism: A case study of UK travel to Southern France using life cycle analysis. Journal of Cleaner Production 64(1): 628-638.

Filimonau, V., Dickinson, J., Robbins, D., Reddy, M.V., 2013. The role of 'indirect' greenhouse gas emissions in tourism: Assessing the hidden carbon impacts from a holiday package tour. Transportation Research Part A 54(1): 78-91.

Gössling, S., 2002. Global environmental consequences of tourism. Global Environmental Change 12(4): 283-302.

Gössling, S., 2013. National emissions from tourism: An overlooked policy challenge? Energy Policy, 59: 433-442.

Gössling, S., Peeters, P., Ceron, J.P., Dubois, G., Patterson, T., Richardson, R.B., 2005. The co-efficiency of tourism. Ecological Economics 54(4): $417-434$.

Gössling, S., Scott, D., Hall, C.M., 2015. Inter-market variability in CO2 emission-intensities in tourism: Implications for destination marketing and carbon management. Tourism Management 46: 203-212
Horng, J.S., Hu, M.L., Teng, C.C., Hsiao, H.L., Liu, C.H., 2013. Development and validation of the low-carbon literacy scale among practitioners in the Taiwanese tourism industry. Tourism Management 35: 255-262.

Howitt, O.J.A., Revol, V.G.N., Smith, I.J., Rodger, C.J., 2010. Carbon emissions from international cruise ship passengers' travel to and from New Zealand. Energy Policy 38(5): 2552-2560.

Jia, S.P., Mao, B.H., Liu, S., Sun, Q.P., 2010. Calculation and analysis of transportation energy consumption level in China. Journal of Transportation Systems Engineering and Information Technology 10(1): 23-27. (in Chinese)

Katircioglu, S.T., Feridun, M., Kilinc, C., 2014. Estimating tourism-induced energy consumption and $\mathrm{CO} 2$ emissions: The case of Cyprus. Renewable and Sustainable Energy Reviews 29: 634-640.

Kuo, N.-W., Chen, P.H., 2009. Quantifying energy use, carbon dioxide emission, and other environmental loads from island tourism based on a life cycle assessment approach. Journal of Cleaner Production 17(15): 1324-1330.

Lee, J.W., Brahmasrene, T., 2013. Investigating the influence of tourism on economic growth and carbon emissions: Evidence from panel analysis of the European Union. Tourism Management 38: 69-76.

Li, M.M., Wu, B.H., Cai, L.P., 2008. Tourism development of World Heritage sites in China: A geographic perspective. Tourism Management 29(2): 308-319.

Lin, T.P., 2010. Carbon dioxide emissions from transport in Taiwan's national parks. Tourism Management 31(2): 285-290.

Liu, J., Feng, T.T., Yang, X., 2011. The energy requirements and carbon dioxide emissions of tourism industry of Western China: A case of Chengdu city. Renewable and Sustainable Energy Reviews 15(6): 2887-2894

Mayor, K., Tol, R.S.J., 2010. Scenarios of carbon dioxide emissions from aviation. Global Environmental Change 20(1): 65-73.

Ministry of Industry and Information Technology Chinese (MIITC), 2010. The notice of fuel consumption on Light vehicle. Available at http:// gzly.miit.gov.cn:8090/datainfo/miit/babs2.jsp.

Munday, M., Turner, K., Jones, C., 2013. Accounting for the carbon associated with regional tourism consumption. Tourism Management 36(1): 35-44.

National Bureau of Statistics (NBS), 2011. China's Energy Statistical Yearbook. Beijing: China Statistics Press, (in Chinese).

Nielsen, S.P., Sesartic, A., Stucki, M., 2010. The greenhouse gas intensity of the tourism sector: The case of Switzerland. Environmental Science and Policy 13(2): 131-140.

Peeters, P., Dubois, G., 2010. Tourism travel under climate change mitigation constraints. Journal of Transport Geography 18(3): 447-457.

Peeters, P., Szimba, E., Duijnisveld, M., 2007. Major environmental impacts of European tourist transport. Journal of Transport Geography 15(2): 83-93.

Peleggi, M., 1996. National Heritage and global tourism in Thailand. Annals of Tourism Research 23(2): 432-448.

Saenz-de-Miera, O., Rosselló, J., 2013. Tropospheric ozone, air pollution and tourism: A case study for Mallorca. Journal of Sustainable Tourism 21(8): 1232-1243.

Saenz-de-Miera, O., Rosselló, J., 2014. Modeling tourism impact on air pollution: The case study of PM10 in Mallorca. Tourism Management 40: 273-281

Sun, Y.Y., 2014. A framework to account for the tourism carbon footprint at island destinations. Tourism Management 45: 16-27.

Tamirisa, N.T., Loke, M.K., Leung, P.S., Tucker, K.A., 1997. Energy and tourism in Hawaii. Annals of Tourism Research 24(2): 390-401.

Tang, Z., Shang, J., Shi, C., Liu, Z., Bi, K.X., 2014. Decoupling indicators of $\mathrm{CO}_{2}$ emissions from the tourism industry in China: 1990-2012. Ecological Indicators 46: 390-397.

Teo, P., Huang, S., 1995. Tourism and heritage and heritage conservation in Singapore. Annals of Tourism Research 22(3): 589-615. 
UNWTO, and UNEP (prepared by Scott, D., Amelung, B., Becken, S., Ceron, J.P., Dubois, G., Gossling, S., Peeters, P., Simpson, M.C.), 2008. Climate Change and Tourism: Responding to Global Challenges. World Tourism Organisation, Madrid.

Weaver, D.B., 2011. Contemporary tourism heritage as heritage tourism evidence as heritage tourism: Evidence from Las Vegas and Gold Coast. Annals of Tourism Research 38(1): 249-267.

Wu, P., Shi, P.H., 2011. An estimation of energy consumption and $\mathrm{CO}_{2}$ emissions in tourism sector of China. Journal of Geographical Sciences 21(4): 733-745.

Wulingyuan Bureau of Statistics (WBS), 2005. Wulingyuan Statistical yearbook (1989-2004). Beijing: China Statistics Press. (in Chinese)
Wulingyuan Bureau of Statistics (WBS), 2011. Wulingyuan Statistical yearbook (2005-2010). Beijing: China Statistics Press. (in Chinese)

Xu, J., Yao, L., Mo, L, 2011. Simulation of low-carbon tourism in world natural and cultural heritage areas: An application to Shizhong District of Leshan City in China. Energy Policy 39(7): 4298-4307.

You, F., Hu, D., Zhang, H.T., Guo, Z., Zhao, Y., Wang, B., Yuan, Y., 2011. Carbon emissions in the life cycle of urban building system in China: A case study of residential buildings. Ecological Complexity 8(2): 201-212. 